\title{
A Comparative Corpus-Based Content Analysis of Head of Government AdDRESSES IN RESPONSE TO THE COVID-19 PANDEMIC: JAPAN AND WeSTERn COUNTRIES
}

\author{
Nagisa MORITOKI ŠKOF \\ University of Ljubljana, Slovenia \\ nagisa.moritokiskof@ff.uni-lj.si
}

\begin{abstract}
Addresses made by heads of government reflect their views and opinions. This article presents a quantitative content analysis of public addresses made by heads of government of the five countries, namely Japan, the USA, New Zealand, Germany, and Slovenia, which were done in response to the novel coronavirus (Covid-19). Word frequency analysis and hierarchical cluster analysis were used to identify the content specifics of these addresses. The comparative analysis of speeches concerning the novel coronavirus enables us to determine how these addresses reflect the speakers' perspectives and political orientation and what they attempted to convey to the public.
\end{abstract}

Keywords: content analysis; head of government; public address; analysis of characteristic words; hierarchical cluster analysis

\section{Povzetek}

Nagovori voditeljev vlad odražajo njihova stališča in mnenja. Ta članek predstavlja kvantitativno vsebinsko analizo javnih nagovorov voditeljev vlad petih držav, in sicer Japonske, ZDA, Nove Zelandije, Nemčije in Slovenije, ki so bili izvedeni kot odziv na novi koronavirus (Covid-19). Za prepoznavanje vsebinskih posebnosti teh nagovorov smo uporabili analizo frekvence besed in hierarhično analizo gruč. Primerjalna analiza nagovorov v povezavi z novim koronavirusom nam omogoča, da ugotovimo, kako ti nagovori odražajo perspektivo govorcev in politično usmeritev govorcev ter kaj so govorci poskušali sporočiti javnosti.

Ključne besede: analiza vsebine; voditelji(ce) držav; javni nagovor; analiza karakterističnih besed; analiza hierarhičnih razmerij 


\section{Introduction}

In January 2020, the novel coronavirus shook the global public. As infections spread from China, the virus rapidly reached other states across Asia, Oceania, and Europe. With the growing number of ill and deceased, health facilities felt pressure to act as never before. National leaders implemented various measures to deal with the crisis, including the provision of accurate public information, setting up health systems equipped to treat infected patients, restricting freedom of movement, providing financial assistance to small business owners and the newly unemployed, among others. The virus made a strong impact on the lives of people who had thus far been accustomed to freedom of movement and unrestricted public gathering. National leaders addressed their citizenry at the beginning of the pandemic outbreak, outlining the gravity of the situation caused by the novel coronavirus.

Addresses made by heads of government reflect their views and opinions. A public address is also an important factor in influencing public opinion (Katz, 1957; Scheufele \& Shah, 2000; Nisbet, 2006). This article presents a quantitative content analysis of the public addresses made by five heads of government in response to the novel coronavirus and attempts to highlight the particularities of the Japanese address. These are then compared so as to explore them in greater detail and to try and explain what the leaders wished to convey to the public.

The purpose of this contribution is not to criticize individual governments or the policies of their leadership but to employ an objective analysis of the speeches made in response to the novel coronavirus in different states. A detailed linguistic and quantitative analysis is employed for this purpose.

\section{Content analysis and political speech}

Social life comprises speaking, writing, reading, and listening - the expression and acceptance of ideas and desires using language. This means that our social activities can be explained by analyzing the content of the language we use for expression. Text content-analysis began in the second half of the 17th century when the Roman Catholic Church feared that non-religious printed matter could threaten the authority of the church and began to analyze the content of printed matter to eliminate non-religious printed matter and preserve its authority. In more modern times, quantitative analyses of newspaper and magazine articles appeared in the late 19th and early 20th centuries (Wilcox 1900), followed by content analyses of radio and television news broadcasts.

The world wars motivated analyses of propaganda, and the post-war period boasted analyses of the will of the populace (Lasswell 1949). When the popularization of computer technology in the 1980s made it possible for texts to be analyzed by a wider audience and van Dijk (1993) simultaneously emphasized the need for linguistic 
discourse analysis at the level of the text as opposed to being confined to individual words, phrases and sentences, the popularity of text content analysis further grew. Today, content analysis is not limited to mass media, political speech, or literary critique. An analysis of Twitter comments during the 2009 spread of the H1N1 virus (Chew and Eyenbachx 2010), Facebook content analysis during the 2008 American presidential election (Fernandes et al. 2010), and similar analyses of social media (Hsieh and Shannon 2005; Elo and Kyngäs 2008; Skalski et al. 2017) point to just how far content analysis has come today.

This article offers an analysis of public addresses made by five heads of government to their citizens. These speeches may provide an insight not only into the speakers' opinions on the situation and impending measures (Grimmer and Stewart 2013) but also on their political orientation (Pitofsky 1978; Suzuki and Kageura 2011; Krippendorff 2018).

In the addresses analyzed in this article, heads of government explain to their citizens the circumstances surrounding the novel coronavirus and ask for an understanding of the measures they would be forced to implement. We are by now familiar with the leaders' addresses to the public during times of earthquakes, other natural disasters, or war. In this instance, a comparative analysis of speeches concerning the novel coronavirus enables us to determine how these addresses reflect the perspectives and political orientation of the speaker.

\section{Data and methodology}

Speeches of five heads of government were selected for this analysis - those of Japan, the USA, New Zealand, Germany, and Slovenia. The head of government public addresses of Japan, the USA, Germany, and Slovenia are accessible on the respective government websites. English language translations are also available alongside their source documents in Japan, Germany, and Slovenia and were used for this analysis. Due to their close political, economical, and cultural ties, the USA and Germany were added to the originally selected case studies of Slovenia and Japan. The New Zealand head of government address was selected because of the state's location in Oceania and its geographical similarity to Japan. ${ }^{1}$

Texts were analyzed using KH Coder (third version). KH Coder software is used for quantitative content analysis and text mining using methods that include KWIC concordance, collocation statistics, co-occurrence network, correspondence analysis,

\footnotetext{
${ }^{1}$ Because the government publication of the New Zealand head of government address was not accessible in Slovenia, Dr. Masayoshi Ogino (University of Canterbury, New Zealand) assisted us with access to the publication on Newshub - a website that provides access to radio, television, and digital media news.
} 
self-organizing map, and others. For the purpose of this article, the methods of word frequency analysis and hierarchical cluster analysis were used.

$\mathrm{KH}$ Coder uses Stanford POS Tagger software for the morphological analysis of the English language. The table below lists details of the addresses given in each state.

Table 1: Data on head of government public addresses in response to the novel coronavirus

\begin{tabular}{llllcc}
\hline Country & Speaker & Speaker's title & $\begin{array}{l}\text { Date of } \\
\text { address }\end{array}$ & $\begin{array}{c}\text { No. of } \\
\text { sentences }\end{array}$ & $\begin{array}{c}\text { No. of words } \\
\text { (different words) }\end{array}$ \\
\hline Japan & Shinzō Abe & Prime Minister & 7.4 .2020 & 133 & $3036(840)$ \\
USA & Donald Trump & President & 11.3 .2020 & 74 & $1415(502)$ \\
New Zealand & Jacinda Ardern & Prime Minister & 23.3 .2020 & 120 & $2031(538)$ \\
Germany & Angela Merkel & Chancellor & 18.3 .2020 & 106 & $2151(581)$ \\
Slovenia & Janez Janša & Prime Minister & 19.3 .2020 & 99 & $2066(641)$ \\
\hline
\end{tabular}

The head of government public addresses are analyzed and differences between them are highlighted in the sections that follow.

\section{Comparison between states: an analysis of ten characteristic words}

In the previous section, comparisons of ten most characteristic words in each head of government address were used to determine the particularities of the speeches. In the following section, the addresses are examined in somewhat greater detail using the method of hierarchical clustering. Approximately 30 nouns and verbs are analyzed using the Jaccard coefficient ${ }^{2}$ and the Ward method ${ }^{3}$, the most commonly used methods in content analysis. This is used to provide an explanation of the characteristics of the head of government addresses made in the five states and illustrates the circumstances and positions therein described.

\footnotetext{
${ }^{2}$ The Jaccard coefficient is to measure the distance between a particular case and a centroid. It considers the occurrence of a code, not its frequency in a particular text (Oleink, 2011, p. 867).

${ }^{3}$ The Ward method is used as the clustering algorithm, which assesses cluster membership by computing the total sum of squared deviations from the mean of a cluster. It uses dissimilarities between variables to form clusters. (Tayler, et al., 2012, p. 39)
} 
Table 2: The number of nouns and the number of different nouns in the head of government addresses

\begin{tabular}{lcc}
\hline Country & Number of nouns & Number of different nouns \\
\hline Japan & 659 & 322 \\
USA & 276 & 171 \\
New Zealand & 369 & 181 \\
Germany & 347 & 202 \\
Slovenia & 390 & 223 \\
\hline
\end{tabular}

The table below lists the top ten characteristic words in the head of government addresses.

Table 3: The ten most characteristic words in the head of government addresses

\begin{tabular}{|c|c|c|c|c|c|c|c|c|c|}
\hline Japan & $\mathrm{JC}^{*}$ & USA & $\mathrm{JC}$ & New Zealand & $\mathrm{JC}$ & Germany & $\mathrm{JC}$ & Slovenia & $\mathrm{JC}$ \\
\hline people & 0.151 & 1 virus & 0.139 & case & 0.085 & 5 time & 0.073 & 3 government & 0.094 \\
\hline number & 0.086 & 5 action & 0.099 & time & 0.079 & 9 life & 0.071 & crisis & 0.076 \\
\hline facility & 0.076 & health & 0.088 & service & 0.073 & 3 community & 0.044 & 4 time & 0.075 \\
\hline life & 0.072 & nation & 0.067 & home & 0.055 & 5 way & 0.043 & 3 everyone & 0.071 \\
\hline patient & 0.068 & travel & 0.065 & today & 0.054 & 4 everyone & 0.042 & 2 measure & 0.071 \\
\hline effort & 0.067 & world & 0.062 & way & 0.054 & 4 day & 0.041 & 1 equipment & 0.071 \\
\hline business & 0.066 & restriction & 0.049 & transmission & 0.050 & 0 democracy & 0.035 & day & 0.070 \\
\hline cooperation & 0.061 & American & 0.041 & hour & 0.049 & 9 reason & 0.038 & country & 0.065 \\
\hline infection & 0.059 & outbreak & 0.041 & community & 0.047 & 7 restriction & 0.036 & epidemic & 0.059 \\
\hline situation & 0.056 & relief & 0.041 & decision & 0.041 & 1 thing & 0.036 & 5 place & 0.044 \\
\hline
\end{tabular}

*JC: Jaccard coefficient

The central theme of each head of government address may be deduced with the help of the Table 3 above. Nouns related to the economy and society have a high Jaccard coefficient in the Japanese and American addresses and there are fewer nouns that relate to everyday life. In the Japanese address, the word 'people' is particularly common. The Japanese address is not as focused on the methods and measures of dealing with the emergent crisis, providing instead more of an explanation of the circumstances and asks for understanding. The word 'virus' has a particularly high coefficient and there is a frequent demand for action in the American address. The words 'nation', 'American' and 'world' also appear. 
By contrast, the New Zealand address includes the word 'community', as well as 'time', 'today' and 'hour', suggesting a rapid transmission of the coronavirus. Words like 'community', 'life', and 'democracy' are more prevalent in German speech as is the word restriction. The Slovenian address focuses on the state of emergency of the 'epidemic', the resulting international 'crisis' and draws attention to forthcoming 'measures'.

In the Japanese address, the word 'people' has a relatively high Jaccard coefficient. A careful look at its use reveals that the word 'people' is accompanied by numbers and quantitative adjectives in seven of the twenty-two times it is used. Following are two examples of the use of the word 'people'.

(1) If the infection continues to spread at this pace, two weeks from now more than 10,000 people will be infected, and a month from now that number will top 80,000 . [Japan]

(2) The frightening aspect of this infectious disease is that many people who have contracted it have no fever or other symptoms whatsoever, and it spreads by them infecting people around them without anyone realizing it. [Japan]

It may be observed that the Japanese head of government refers to numerals and quantitative adjectives to provide a more concrete explanation of the situation. Such usage also explains why the noun 'number' is the second most frequently used.

In five of the twenty-two times, the word 'people' is used synonymously with 'citizens'. For example:

(3) We have determined that this situation could cause significant damage to people's daily lives and to the national economy. [Japan]

There are other cases where the word 'people' is used to address the audience synonymous with to use of the pronoun 'you':

(4) I ask people to refrain from going out, aiming at a 70 to 80 percent decrease, for the limited period of one month between now and the end of Golden Week holidays on May 6. [Japan]

Example (4) is an indirect address to the audience using the word 'people', but in the original Japanese text, this word corresponds neither with the semantic connotation in the sense of the word 'people' nor it is synonymous with the pronoun 'you' as in example (5). 
(5) その効果を見極める期間も含め、ゴールデンウイークが終わる

Sono kōka o mikiwameru kikan mo fukume, gōrudenuīku ga owaru

5 月 6 日までの 1 か月に限定して、7 割から 8 割

gogatsu muika madeno ikkagetsu ni genteishite, nanawari kara hachiwari

削減を目指し、外出自肃をお願いいたします。

sakugen o mezashi, gaishutsu jishuku o onegai itashimasu.

This makes it impossible to determine whether such use of the word 'people' is actually derived from the Japanese expression when giving a speech or from the translator's choice of words. It is however clear that in his request that advised measures be followed, the Japanese Prime Minister avoids addressing the public directly and instead uses an expression that applies to all citizens, and therefore, to the entire audience. In this way, he asks the public for 'cooperation' that will enable them to overcome the current 'situation'.

\section{A comparison of different states: analysis using the method of hierarchical clustering of nouns and verbs}

In the previous section, a comparison of the ten most characteristic noun words in each head of government address was used to determine the particularities of the speeches. In the following section, the addresses are examined in somewhat greater detail using the method of hierarchical clustering. Approximately 30 nouns and verbs are analyzed using the Jaccard coefficient and the Ward method. In this way we will be able to provide an explanation of the characteristics of the head of government addresses made in the five states and illustrates the circumstances and positions therein described.

\subsection{The Japanese address: 'ask' and 'cooperation'}

The results of the hierarchical cluster analysis of nouns and verbs of the Japanese address are depicted in Figure 1. In the first cluster, the Prime Minister announces action ('action') and asks ('ask') for understanding on the implementation of measures ('measure') that are designed to 'avoid' the spread of infection. In the second, the Prime Minister mentions the danger of being infected by the virus ('infection', 'risk', 'virus') and protecting people's lives ('protect', 'life', 'citizen'), and in the third, he speaks about a state of emergency ('emergency', 'state'). In the fourth cluster, he discusses the ongoing cooperation ('continue', 'cooperation') of citizens with health workers and facilities ('facility') that will receive patients. The fifth cluster refers to the number of patients ('number', 'patient'), which must be reduced ('reduce'). The final 
cluster refers to the economy. Here, he calls on people to exert effort in overcoming the coronavirus.

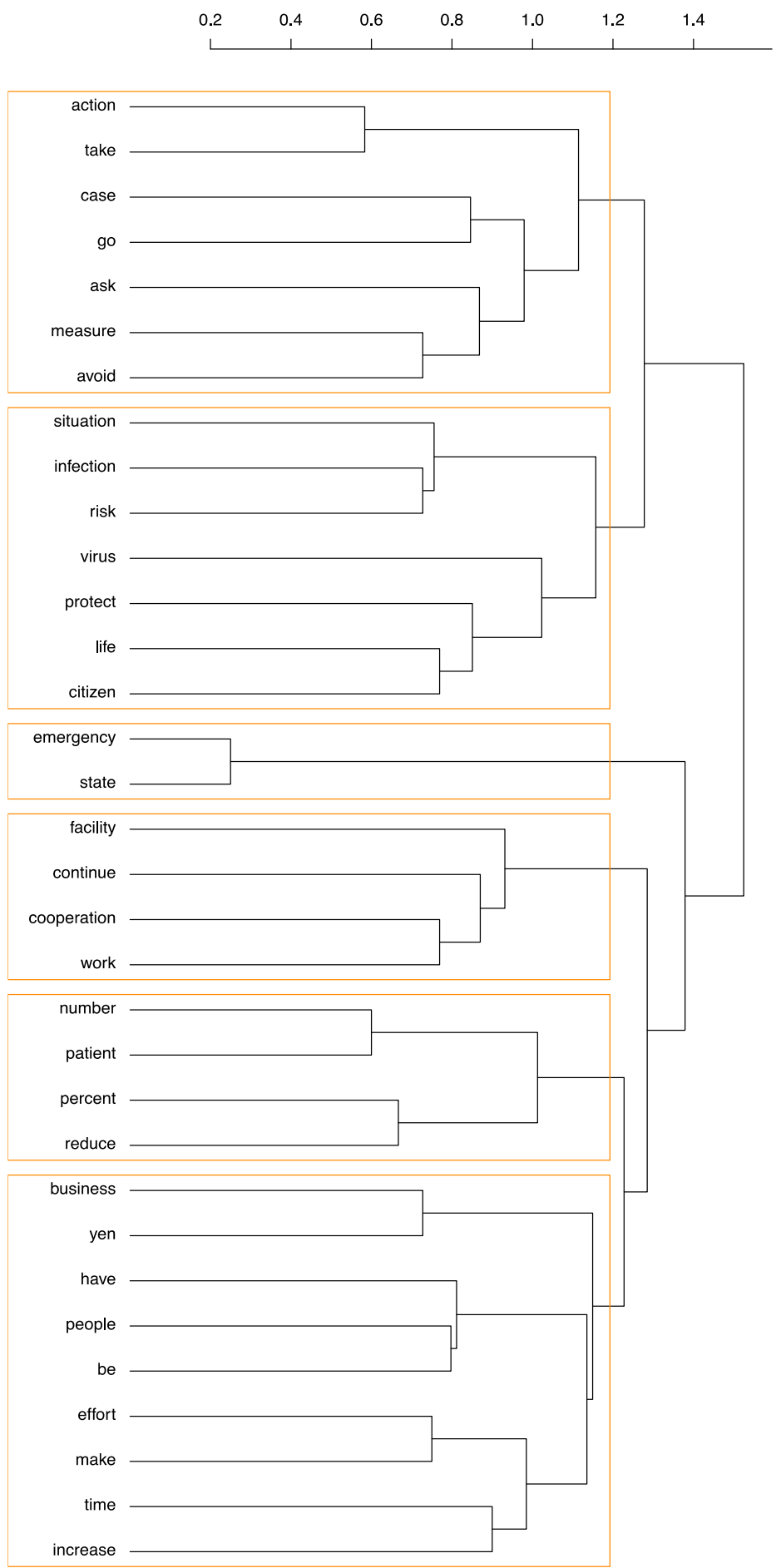

Figure 1: Hierarchical clustering of nouns and verbs (33 words) of the Japanese address 
The Japanese address mentions specific amounts when referring to the provision of financial assistance during the pandemic.

(6) Towards that end, we have decided to implement economic measures at a scale of 108 trillion yen, equivalent to 20 percent of our GDP, which is even one of the largest in the world. [Japan]

(7) For businesses whose sales have dropped significantly, we will provide 2 million yen to small- and medium-sized corporations as well as those relatively larger corporations and 1 million yen to individual owners. [Japan]

One of the particularities of the Japanese address is the frequent use of the word 'ask'. The table below illustrates the number of times the verb 'ask' and the noun 'restriction' appear in the addresses of each head of government.

Table 4: Frequency of appearance of the words 'ask' and 'restriction'

\begin{tabular}{lccccc}
\hline Row & Japan & USA & New Zealand & Germany & Slovenia \\
\hline Ask & 14 & 2 & 5 & 1 & 2 \\
Restriction & 0 & 4 & 2 & 4 & 2 \\
\hline
\end{tabular}

The word 'ask' notably appears very frequently in the Japanese address. By contrast, the keyword restriction, which in the American and German addresses occupies seventh and ninth place in the characteristic words, respectively, was not used in the Japanese address at all. The reason for its absence may be attributed to the fact that it was not possible to impose restrictions ('measure', 'restriction') concerning the novel coronavirus in Japan. Consequently, the leadership could provide citizens only with advice on how to curb the spread of the virus.

Also common in the Japanese address are the words effort (sixth-most characteristic word) and cooperate or cooperation ('cooperation'; eighth-most characteristic word).

Table 5: Frequency of appearance of the words 'effort' and 'cooperate/cooperation'

\begin{tabular}{lccccc}
\hline Row & Japan & USA & New Zealand & Germany & Slovenia \\
\hline effort & 9 & 1 & 0 & 1 & 1 \\
cooperate/cooperation & 9 & 0 & 0 & 0 & 3 \\
\hline
\end{tabular}


Below are two examples of the use of the word 'effort'.

(8) However, even with many such efforts underway, the number of patients is soaring, particularly in urban areas such as Tokyo and Osaka. [Japan]

(9) The business owners who are now gritting their teeth and making their best efforts now in the midst of this truly tough time present Japan's underlying strength. [Japan]

The phrase such efforts in example (8) refers to the passage of the address that directly precedes it: 'Owing to the cooperation with healthcare institutions, electronics manufacturers and hotels, a healthcare system for receiving infected persons has already been established in Japan.' Example (9) emphasizes people, especially smalland medium-sized business owners who must continuously invest effort into their work, which has now only been exacerbated by the novel coronavirus epidemic.

This may be compared with the use of the word effort in the Slovenian address.

(10) Everyone with a command of military knowledge and skills who is not working in a critical job is invited to volunteer to join the collective effort to provide general security. [Slovenia]

'Effort' in the Slovenian address refers to tackling difficult obstacles that must be overcome to reach a particular goal. On the contrary, the choice of words is somewhat different in the Japanese address, where it is suggested that something is always urgently required to maintain the set goal. This reflects another particularity unique to the Japanese address.

'Cooperate/cooperation' appears nine times in the Japanese and three times in the Slovenian address. Following is one example from each.

(11) I ask for your cooperation once more. Even in the midst of total uncertainty and great unease, hope is unmistakably emerging. [Japan]

(12) Thanks are due to the members of the Civil Protection Service throughout the country, and to all of the members of the Crisis Staff, who responded without hesitation to my request to cooperate. [Slovenia]

In both addresses, the word cooperation is used to express the desire for people to act. The difference lies in this being expressed as a request (ask) in the Japanese address, while in Slovenian, the Prime Minister links this expression to his leadership ability since the Crisis Staff decided to act on his initiative. In his address, the Japanese 
Prime Minister expresses gratitude to individuals and to local governments for their cooperation.

(13) I appreciate sincerely the cooperation of each and every citizen. Quite frankly, we cannot overcome this state of emergency through sole efforts by the national and local governments. [Japan]

The Japanese address is not about overcoming the crisis owing to the Prime Minister's leadership ability, but about expressing a desire for people to cooperate since this is the only means by which they can overcome the virus.

\subsection{The American address: 'action' and 'economy'}

The results of the analysis of 31 verbs and nouns are depicted in Figure 2 . In the first cluster, the President draws attention to economic threats (business, emergency) and uses the promise of action in an effort to calm the citizenry. This is followed by information on the restriction of travel ('restriction', 'travel') (second cluster), protecting people ('protect', 'people') against health risk ('health', 'risk') (third cluster), the treatment ('treatment') of patients, and reducing ('reduce') the number of those infected by the virus ('virus'), which is a threat ('threat') (fourth cluster) and of conditions at that particular point in time ('time'), which poses a challenge ('challenge') to what the country must overcome ('overcome') (fifth cluster). The final cluster includes expressions related to the outbreak ('outbreak'), the economy ('economy'), and the comparison of the USA ('nation') to the rest of the world ('world'). 


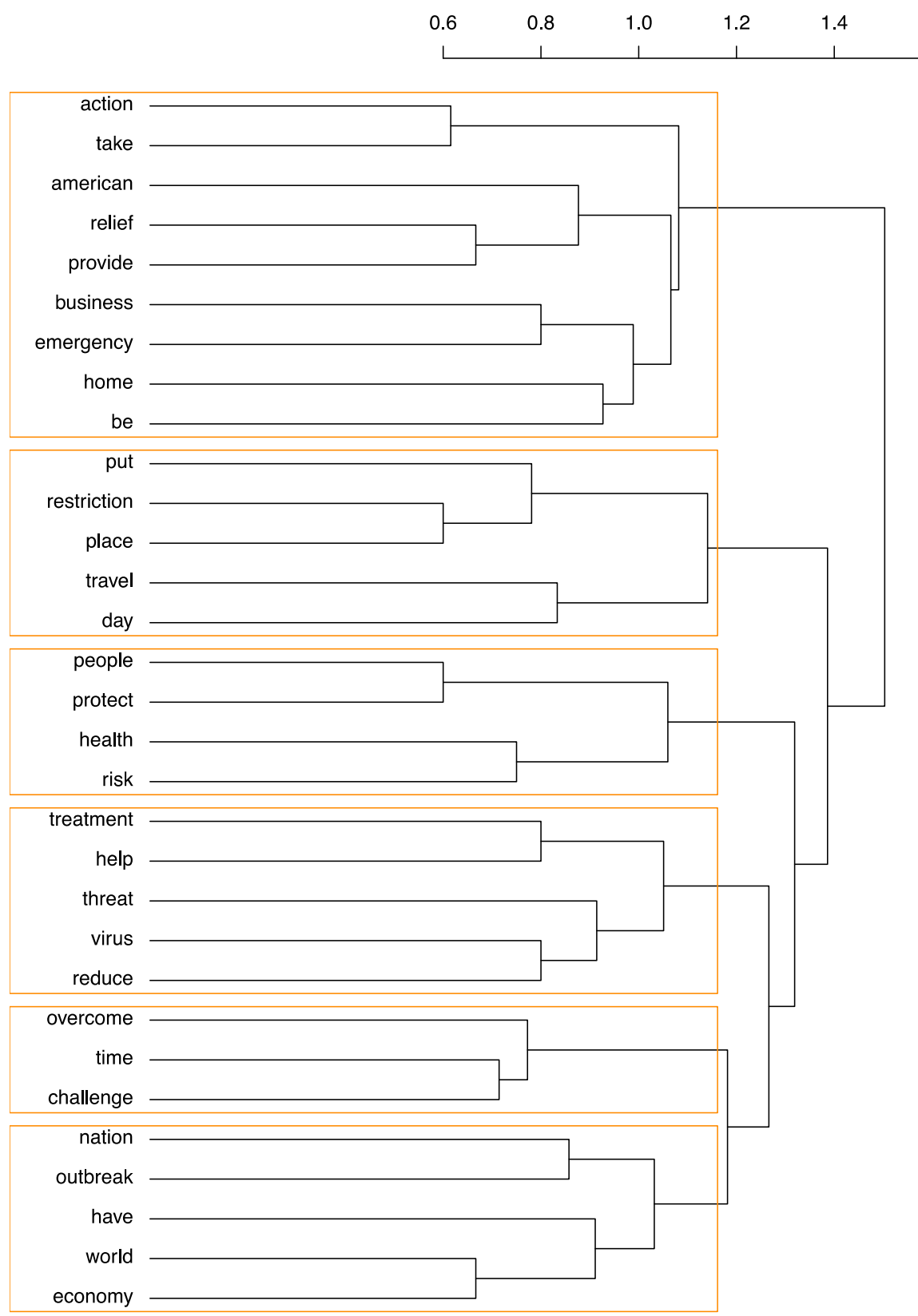

Figure 2: Hierarchical clustering of nouns and verbs (31 words) of the American address

A characteristic of the American address is warning people to stay at home ('home'). Several categories also include expressions related to the economy ('economy', 'business') (first cluster), 'economy' (sixth cluster)), as is evident in examples (14) and (15). 
(14) These low-interest loans will help small businesses overcome temporary economic disruptions caused by the virus. To this end, I am asking Congress to increase funding for this program by an additional $\$ 50$ billion. [USA]

(15) This action will provide more than $\$ 200$ billion of additional liquidity to the economy. [USA]

The address of the President of the United States also lists concrete monetary values concerning economy. The address indicates that there is a greater focus on providing support for the economy.

Another particularity of the American address is the use of proper names of states, which appears more frequently in the American address than it does in others. Proper names were not included in the analysis of the ten characteristic words in Section 4 or the hierarchical clustering method analysis in the current section but are provided in the Table 6 below.

Table 6: Use of proper names of states and regions that appear in the address of the President of the United States

\begin{tabular}{lc}
\hline State, Region & Frequency of repetitions \\
\hline Europe/European Union & 6 \\
China & 5 \\
The United Kingdom & 1 \\
South Korea & 1 \\
\hline
\end{tabular}

Below are two examples of the use of the proper names 'European Union' and 'China'.

(16) The European Union failed to take the same precautions and restrict travel from China and other hotspots. [USA]

(17) We made a lifesaving move with early action on China. [USA]

The American address was delivered in March 2020, when the coronavirus that was first reported in China spread across Europe with explosive speed. For this reason, the President criticizes the EU for failing to curb the number of visitors from China, and China, which presumably failed to implement measures to protect those infected in time. 
Italy is mentioned once in both the Slovenian and New Zealand addresses:

(18) We were watching the events unfold in northern Italy and we didn't believe that the virus could get here faster than Rome or Sicily. [Slovenia]

(19) We currently have 102 cases. But so did Italy once. Now the virus has overwhelmed their health system and hundreds of people are dying every day. [New Zealand]

In the Slovenian and New Zealand head of government addresses, Italy is mentioned as an example of a country where the infection began to spread early but no criticism of Italy is discernible. It may thus be concluded that the President of the United States adopted a much more critical view of China and the EU compared to other heads of government.

\subsection{The New Zealand address: 'Stay' and 'home'}

Following is the analysis of the New Zealand head of government address. Like the United States, New Zealand is part of the English-speaking world and like Japan, it is an island country in Oceania. In this sense, it may be deduced that, in regard to the spread of disease, the perspective of the head of government of an island state may differ from the perspectives of the heads of government of mainland states which share direct land borders with other countries.

The results of the hierarchical clustering analysis of nouns and verbs are depicted in Figure 3. Given that the Prime Minister delivered her speech just 48 hours ahead of implementing measures, the expressions that frequently appear in the New Zealand address include 'time' (sixth cluster), 'today' (fourth cluster), and 'hour' (first cluster). The word time is the second most characteristic word, 'today' is the fifth, and 'hour' is the eighth. This characteristic word 'hour' already becomes apparent in the first cluster, which is concerned with access to services changing over time. 


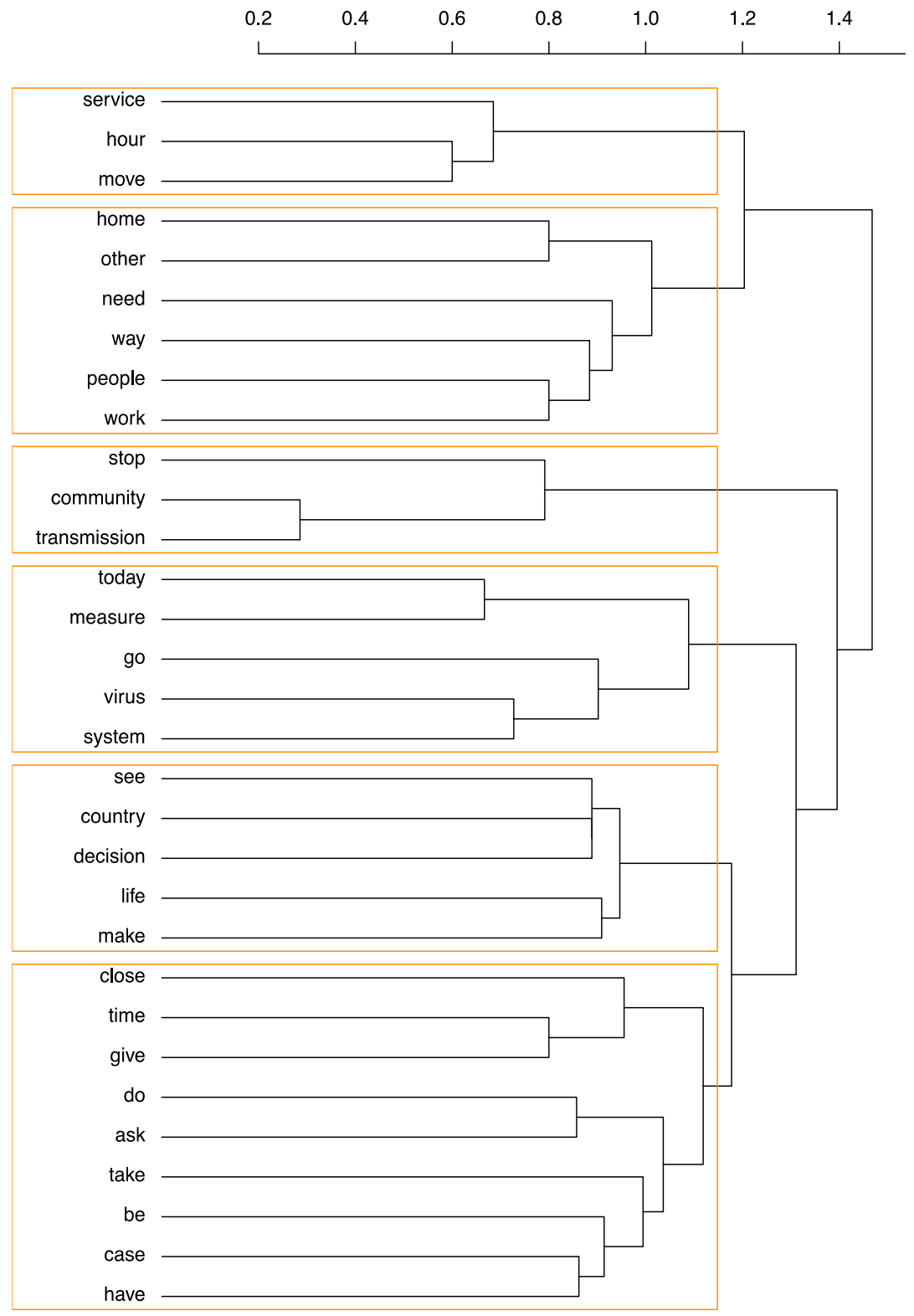

Figure 3: Hierarchical clustering of nouns and verbs (31 words) of the New Zealand address

The second cluster contains phrases related to work ('work') from home ('home'). The third is related to the stop of transmission of disease within the community ('community'). The fourth notes that from the day of the delivery of the speech onwards ('today'), measures ('measure') will be implemented, and acknowledges that the virus threatens the system ('system') - in this case, the health system. The fifth cluster indicates that this is a decision ('decision') of the entire country ('country'), and the last cluster is concerned with the closure ('close') of educational and other institutions, and with the cases ('case') of infection. 
In the New Zealand address, the word 'transmission' is used six times and is the seventh most characteristic word. In those six times used it four times appears in the form of a compound noun 'community transmission'.

Following are the examples from the New Zealand address.

(20) Right now, we have a window of opportunity to break the chain of community transmission - to contain the virus - to stop it multiplying and to protect New Zealanders from the worst. [New Zealand]

In example (20) the head of government voices the opinion that stopping the transmission of the virus in the community is of paramount importance. The word 'home' appears in the address seven times, placing it in the fourth place of the ten most characteristic words (Table 3).

(21) Staying at home is essential. [New Zealand]

(22) To be absolutely clear we are now asking all New Zealanders who are outside essential services to stay at home, and to stop all interactions with others outside of those in your household. [New Zealand]

In the New Zealand address, the Prime Minister tells the citizenry that the most effective way to prevent infection with the novel coronavirus is to stay at home and to cut off contact with the community. Because the virus is spread through everyday social interaction, the Prime Minister requests that people do not leave their homes.

\subsection{The German address: 'democracy' and 'community'}

Analysis of the German address follows. The results of the hierarchical clustering of nouns and verbs are depicted in Figure 4. 


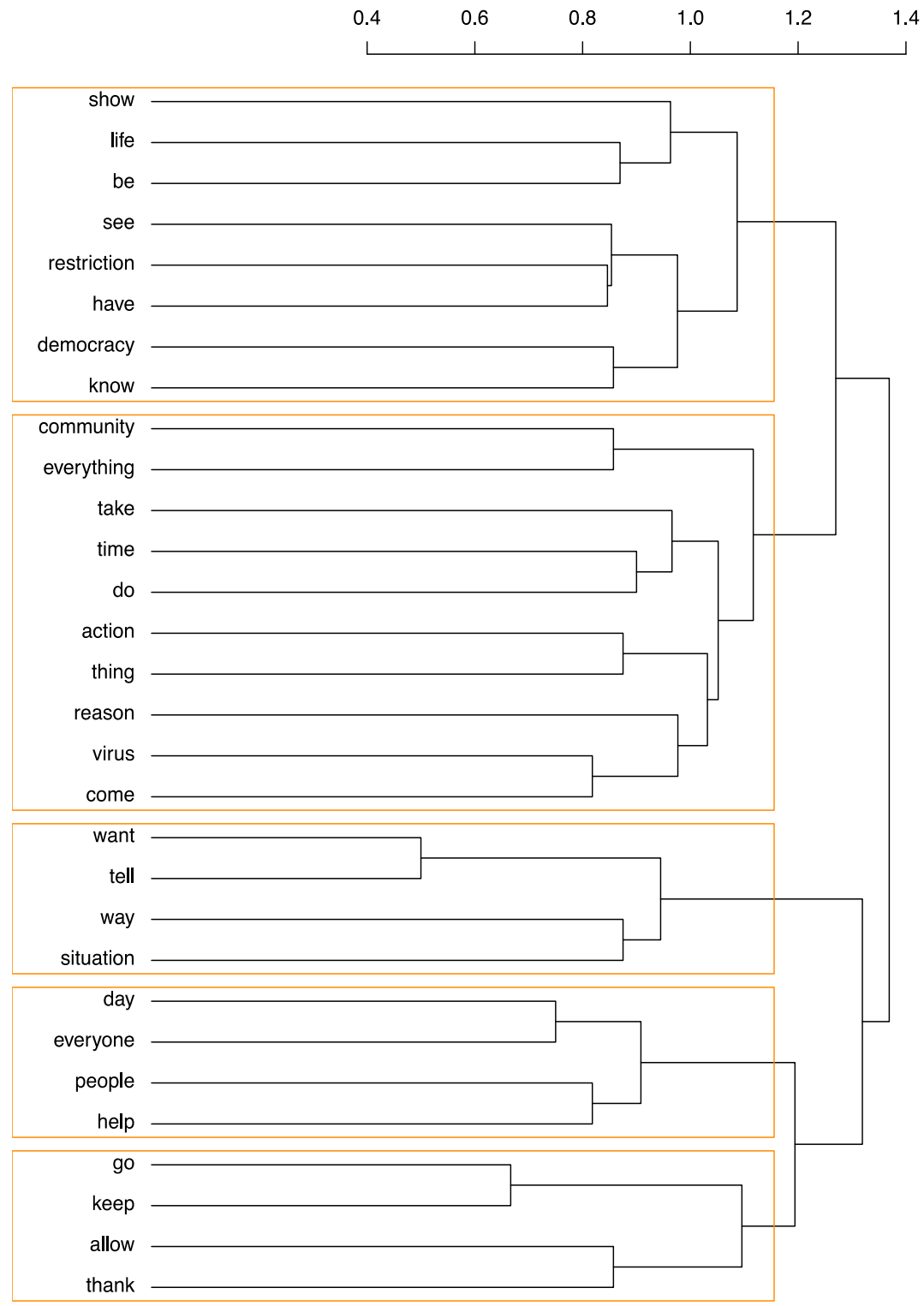

Figure 4: Hierarchical clustering of nouns and verbs (30 words) of the German address

In the first cluster, the word restriction ('restriction') appears alongside the seemingly incompatible expression democracy ('democracy'). Here, the Chancellor discusses the link between measures being implemented against the novel coronavirus and democracy. In the second cluster, she announces that the time ('time') has come for the entire community ('community') to take action ('action') to overcome the virus ('virus'). In the third cluster, she expresses the desire for a clear explanation ('want', 'tell') of the current situation. In the fourth cluster, she emphasizes the meaning of mutual ('everyone', 'people') assistance ('help') and in the fifth, she expresses gratitude ('thank'). 
The word 'democracy' appears four times in the German address and is the seventh most characteristic word. 'Democracy' does not come up in other speeches. The examples below demonstrate the use of the word 'democracy' in the German address.

(23) I know how invasive the closures that the Federation and the Länder have agreed to are in our lives, and also in terms of how we see ourselves as a democracy. [Germany]

(24) These should never be put in place lightly in a democracy and should only be temporary. [Germany]

The Chancellor asserts that the measures and closures during the spread of the novel coronavirus will not violate the rules of democracy. This also explains the simultaneous appearance of the words 'restriction' and 'democracy' in the second cluster. These words are therefore used to emphasize that the temporary restrictions for curbing the spread of the novel coronavirus will not affect the hard-earned democracy that Germany has established since the Second World War.

Like the word 'democracy', the word 'allow' is also a particularity of the German address. Examples (25) and (26) depict the use of the word 'allow'.

(25) And 'allow' me to express my thanks to those who are too seldom thanked. [Germany]

(26) But, above all, time to 'allow' those who fall ill to receive the best possible treatment. [Germany]

In the German address, the word 'allow' appears in the phrasal verb 'allow me' in three of the four times it is used. In example (26), this word is used about the provision of access to medicine for the sick. This use of the word 'allow' demonstrates the attitude of the German Chancellor toward the country's citizens, who she asks for permission to take a particular action.

The word 'allow' also appears twice in the Japanese address, but not in the form of the phrasal verb 'allow me'. Following are examples from the Japanese address.

(27) What is most important to reduce the burdens on medical care is not 'allowing' the number of patients to increase. (Japan)

(28) We must not 'allow' your efforts to come to naught. (Japan)

The word 'allow' that is found in the Japanese address appears in the negative form. This use reflects the urgency in the need to prevent specific dangerous situations. The 
political position conveyed by the use of the word 'allow' in the German address is linked to democracy and to the idea that government action directly serves the people.

\subsection{The Slovenian address: 'war' and 'danger'}

The results of the hierarchical clustering of nouns and verbs are shown in Figure 5 . The first cluster contains phrases that are related to the expression of gratitude ('thank'), the second contains phrases that compare the current situation to the gravity of war ('country', 'state', 'war'), and the third contains phrases related to government measures ('government', 'measure') for curbing the spread of infection ('epidemic'). The fourth cluster contains a reiteration of the expression of gratitude ('thanks'), now clearly directed at citizens ('citizen') and employees. The final cluster refers to Slovenia's preparedness ('provide', 'reserve')) to deal with the current situation ('crisis') in reference to adequate equipment ('equipment').

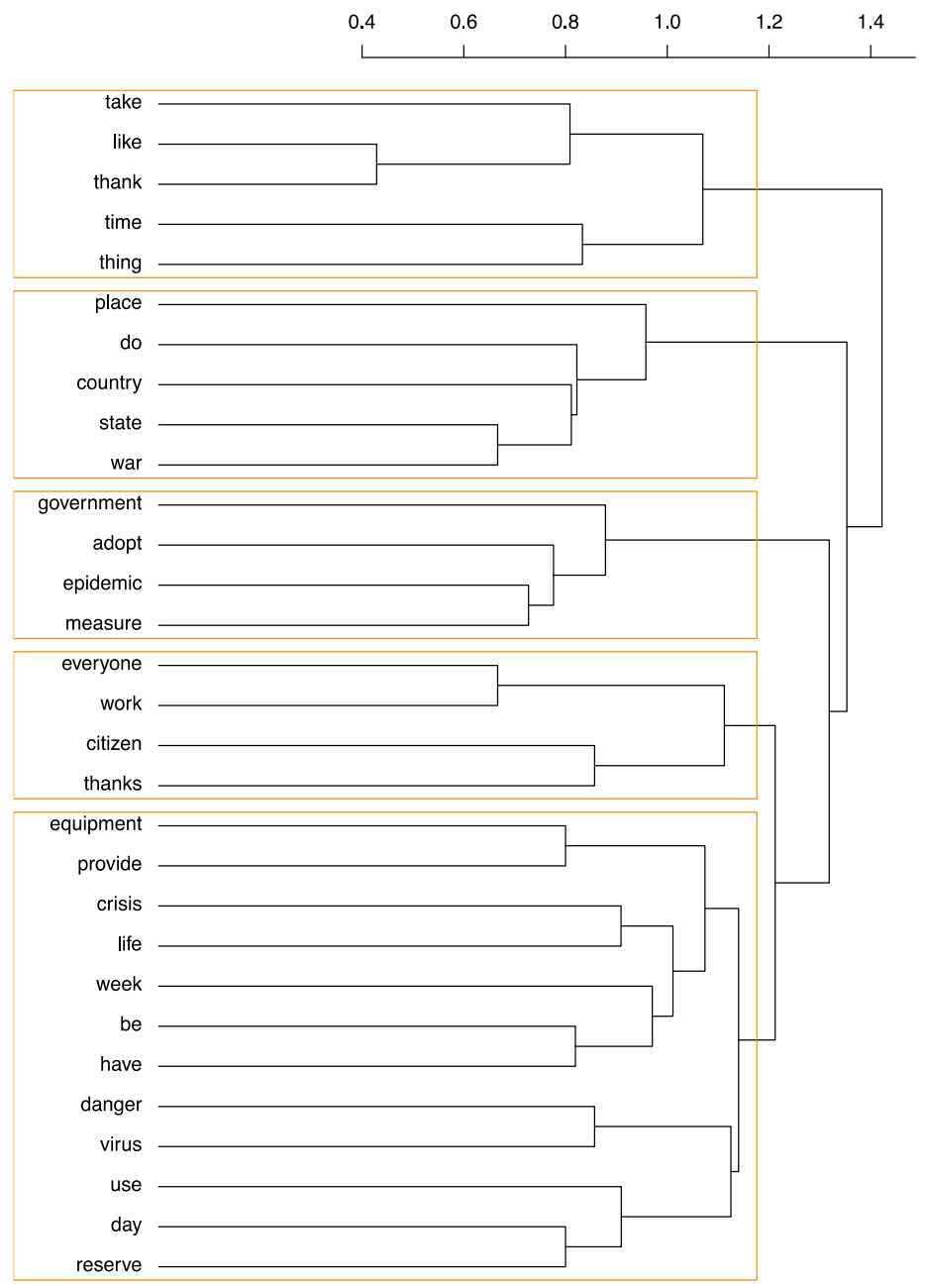

Figure 5: Hierarchical clustering of nouns and verbs (30 words) of the Slovene address 
Following are examples of the use of the word ' $w a r$ ' in the Slovenian address. 'War' is not mentioned in the third section of this study (analysis of the ten characteristic words), as it appears in the Slovenian address only four times. But it appears more frequently and expresses a slightly different meaning of the word by comparison to the other addresses. Below are examples:

(29) The danger is worse than in a traditional war, except when biological weapons are used. [Slovenia]

(30) In Europe today, there are countries that have already been critically affected by the epidemic, countries that due to the epidemic and due to delays are on the edge of chaos and have declared a traditional state of emergency and a state of war, two countries that had adequate defences against epidemics in place, and the majority of others that are improvising, although this is being done by wellestablished and mostly well-organised state apparatuses. [Slovenia]

In the Slovenian address, the Prime Minister describes current circumstances as being potentially worse than war, thereby drawing attention to the gravity of the current situation. In example (30), he refers to the fact that some other countries are also under dangerous circumstances, using the word 'war'.

The word 'war' appears in the German (once) and in the Japanese addresses (twice), as shown below.

(31) Since German reunification, no, since the Second World War, there has not been a challenge for our country in which action in a spirit of solidarity on our part was so important. [Germany]

(32) It is no exaggeration to say that both the global economy and the Japanese economy are now truly facing the greatest crisis in the post-war period. [Japan]

In example (30) and (31) the word ' war' is used to denote a particular point in time (the Second World War). Therefore, in the Slovenian address, the word 'war' highlights the gravity of the current situation, whereas in the German and Japanese addresses, it highlights a concrete point in history.

The following examples contain the word 'danger'. This word appears in the Slovenian address four times but does appear in the other four addresses, except as an indirect adjective in the American address in the form of 'dangerous'. Example (33) illustrates the use of the word 'danger' in the Slovenian address and example (34) illustrates the use of the word 'dangerous' in the American address. 
(33) The danger is worse than in a traditional war, except when biological weapons are used. [Slovenia] (The same as example (29) above)

(34) From the beginning of time, nations and people have faced unforeseen challenges, including large-scale and very dangerous health threats. [USA]

In example (33), the word 'danger' in the Slovenian address is used to highlight the gravity of the current whole situation, whereas in the American address, the word dangerous is used to highlight the harmfulness of the disease. From the use of the words 'war' and 'danger', a conclusion can be made on the views of the Slovenian Prime Minister - he describes the situation as very serious.

\section{Conclusion}

This analysis has compared the contents of addresses made by five heads of government - Japan, USA, New Zealand, Germany, and Slovenia - in the wake of the novel coronavirus. Firstly, ten most characteristic keywords of each address were examined and compared. Based on the results and the hierarchical cluster analysis of verbs and nouns, a comparison of the particularities of all five addresses was implemented. From this data, conclusions were drawn concerning the positions and political orientation of each head of government.

This study has concluded the following results. A particularity of the Japanese address and the address of the President of the United States is the citation of concrete numbers to explain how the government would assist in economic recovery. In the address of the President of the United States, there also appears criticism of other states. A particularity of the Japanese address is the expression of gratitude for the efforts made so far and the request for further cooperation. After World War II, the United States had a strong influence on Japan in politics, economics, and culture. In the two addresses, we see similarities in the heads of government's citations of concrete numbers to explain how the two governments would protect their economies, but we find a significant difference in the leaders' attitude toward their citizenry. In his address, the President of the United States attempts to reassure citizenry with the promise of implementing measures under his leadership, while in Japan, the Prime Minister asks the citizenry for cooperation. Present results suggest that further observation on the leaders' attitudes, their roles in governments, cultural differences when giving a speech, leaders' personalities, and other aspects should be included to make detailed conclusions.

In the New Zealand address, the Prime Minister emphasizes the critical nature of the current situation and asks people to stay home to prevent the uncontrolled spread of the virus within communities. Her approach was not to focus on listing concrete 
measures to be implemented but to express the desire for people to understand what further action they could take to prevent the spread of infection.

The Slovenian address tackles the crisis by the implementation of measures under government leadership. In the German address, the Chancellor points out that measures taken to deal with the novel coronavirus will have an impact on people's lives but also assures this should not compromise democracy, established in Germany after World War II. Notwithstanding the close historical, political and economic ties between Germany and Slovenia, a substantial difference in the focus of their respective leadership may be observed.

Looking at the results of our analysis, we must not forget that the addresses of the heads of government of different states reflect various elements, including the political, such as the role of the head of government, the type of political system and attitude towards citizenry, democracy, and others.

\section{Acknowledgments}

This work was supported by the ARRS under Grant P6-00243 «Asian languages and cultures (Azijski jeziki in kulture) «; I would like to express my gratitude to Dr. Masayoshi Ogino, University of Canterbury in New Zealand for providing me the address of the Prime Minister Jasinda Ardern, and Dr. Kōichi Higuchi, Ritsumeikan University in Japan, whose free software for quantitative content analysis or text mining $\mathrm{KH}$ Coder (ver. 3, https://khcoder.net/en/) I was able to use. Finally, I thank the anonymous reviewers for their careful reading of my manuscript and their many insightful comments and suggestions.

\section{References}

Barker, K., \& Cornacchia, N. (2000). Using noun phrase heads to extract document keyphrases. Conference of the Canadian Society for Computational Studies of Intelligence, 40-52. Springer, Berlin, Heidelberg. https://doi.org/10.1007/3-540-45486-1_4

Chew, C., \& Eysenbach, G. (2010). Pandemics in the age of Twitter: content analysis of Tweets during the 2009 H1N1 outbreak. PloS One 5 (11), e14118. https://doi.org/10.1371/journal.pone.0014118

Danowski, J. A., \& Park, D. W. (2009). Networks of the dead or alive in cyberspace: Public intellectuals in the mass and internet media. New Media \& Society, 11 (3), 337-356. https://doi.org/10.1177/1461444808101615

Elo, S. \& Kyngäs, H. (2008). The qualitative content analysis process. Journal of Advanced Nursing 62 (1), 107-115. https://doi.org/10.1111/j.1365-2648.2007.04569.x 
Fernandes, J., Giurcanu, M., Bowers K. W. \& Neely, J. C. (2010). The writing on the wall: A content analysis of college students' Facebook groups for the 2008 presidential election. Mass Communication and Society 13 (5), 653-675. https://doi.org/10.1080/15205436.2010.516865

Grimmer, J. \& Stewart, B. M. (2013). Text as data: The promise and pitfalls of automatic content analysis methods for political texts. Political Analysis 21 (3), 267-297, 2020/11/28. https://doi.org/10.1093/pan/mps028

Hsieh, H. F., \& Shannon, S. E. (2005). Three approaches to qualitative content analysis. Qualitative Health Research 15, 1277-1288. https://doi.org/10.1177/1049732305276687

Katz, E. (1957). The Two-Step Flow of Communication: An Up-to-Date Report on an Hypothesis. Public Opinion Quarterly, 21, 67-78.

Krippendorff, K. (2018). Content analysis: An introduction to its methodology. California: Sage publications.

Lasswell, H. D. (1949). Why be quantitative? In H. D. Lasswell \& N. Leites, et al. (Eds.), Language of Politics (pp. 40-52). New York: G. W.

https://in.sagepub.com/sites/default/files/upm-assets/19018_book_item_19018.pdf

Lim, E. T. (2002). Five trends in presidential rhetoric: An analysis of rhetoric from George Washington to Bill Clinton. Presidential Studies Quarterly 32 (2), 328-348. https://www.jstor.org/stable/27552390

Nisbet, E. C. (2006). The Engagement Model of Opinion Leadership: Testing Validity Within a European Context. International Journal of Public Opinion Research 18(1), 3-30. https://doi.org/10.1093/ijpor/edh100

Oleinik, A. (2011). Mixing quantitative and qualitative content analysis: Triangulation at work. Quality \& Quantity, 45(4), 859-873. https://link.springer.com/content/pdf/10.1007/s11135-010-9399-4.pdf

Pitofsky, R. (1978). Political content of antitrust. University of Pennsylvania Law Review 127, 1051-1075.

Scheufele, D. A., \& Shah, D. (2000). Personality strength and social capital: The role of dispositional and informational variables in the production of civic participation. Communication Research, 27, 107-131.

Skalski, P. D., Neuendorf, K. A. \& Cajigas J. A. (2017). Content analysis in the interactive media age. In K. A. Neuendorf (Ed.), The Content Analysis Guidebook (pp. 201-242). California: SAGE Publications.

Suzuki, T. 鈴木 崇史, \& Kageura, K. 影浦 峡 (2011). Meishi no bunpu tokuchōryō o mochiita seiji tekisuto bunseki 名詞の分布特徵量を用いた政治テキスト分析 [Political Text analysis using distributional characteristics of nouns]. Kōdōkeiryōgaku 行動計量学 38(1), 83-92. https://doi.org/10.2333/jbhmk.38.83

Taylor, S., Lambeth, D., Green, G., Bone, R., \& Cahillane, M. A. (2012). Cluster analysis examination of serial killer profiling categories: A bottom-up approach. Journal of Investigative Psychology and Offender Profiling 9(1), 30-51.

van Dijk, T. A. (1993). Principles of critical discourse analysis. Discourse \& Societyl 2, 249-283.

Wilcox, D. F. (1900). The American newspaper: A study in social psychology. The Annals of the American Academy of Political and Social Science 16(1), 56-92.

https://www.jstor.org/stable/pdf/1009441.pdf 
Yu, B., Kaufmann S. \& Diermeier D. (2008). Exploring the characteristics of opinion expressions for political opinion classification. Proceedings of the 9th Annual International Conference on Digital Government Research, Montreal, Canada, May 2008, 82-91 https://surface.syr.edu/cgi/viewcontent.cgi ?article=1029\&context=istpub

\section{Appendix}

The address of Japanese Prime Minister Shinzo Abe: Speeches and Statements by the Prime Minister, [Covid-19] Press Conference by the Prime Minister Regarding the Declaration of a State of Emergency. https://japan.kantei.go.jp/98_abe/statement/202004/_00001.html

The address of Slovene Prime Minister Janez Janša: Address to the nation by Slovenian Prime Minister Janez Janša regarding the coronavirus epidemic. (2020, March 19). https://www.gov.si/en/news/2020-03-19-address-to-the-nation-by-slovenian-primeminister-janez-jansa-regarding-the-coronavirus-epidemic/

The address of American President Donald Trump: Remarks: Donald Trump Addresses the Nation on the Coronavirus from The Oval Office - March 11, 2020. (2020, March 11). https://factba.se/transcript/donald-trump-remarks-live-oval-office-coronavirus-march11-2020

The address of German Chancellor Angela Merkel: An address to the nation by Federal Chancellor Merkel. (2020, March 18). https://www.bundeskanzlerin.de/bkinen/news/statement-chancellor-1732302

The address of New Zealander Prime Minister Jacinda Ardern: Coronavirus: Prime Minister Jacinda Ardern's full Covid-19 speech. (2020, March 23). https://www.newshub.co.nz/home/politics/2020/03/coronavirus-prime-ministerjacinda-ardern-s-full-covid-19-speech.html 